\title{
Research on the Supply Side Reform of Higher Education in China
}

\author{
Li Sun \\ Wuhan DonghuUniversity, Wuhan, 430000, China
}

\begin{abstract}
The supply side reform will definitely promote the supply side reform of higher education. Firstly, this paper discusses the concept of the supply side reform of the higher education, and then points out the dilemma of the traditional demand side reform of higher education. We should lead the development of higher education with the supply side reform. The specialty provision optimizing, backward courses reforming, new teachers cultivating and vocational education promoting are the major paths of the supply side reform of China's higher education.
\end{abstract}

Keywords:higher education, supply side reform, demand side reform

\section{Concept of supply side reform of higher education}

PresidentXi Jinping firstly proposed the concept of "supply side reform" at the APEC meeting on November 18, 2015. The demand and supply are a set of concepts in economics. In the history of the development of western economics, the Keynes school advocated the reform of demand side. They believe the economic growth depends on the demand expanding and consumption stimulating. But the West's economic crisis tells us the fact that expanding demand will lead to short supply and inflation. To solve this problem, the supply side put forward to promote economic growth by improving production capacity, rather than through the traditional idea of stimulating social demand to promote economic growth, that is, supply side reform". In addition to the economic field, the status quo of the field of education is not optimistic. Comprehensive reform of education in the field of continuous deepening, China's education service system is becoming more and more perfect, the educational needs of the people 
have been turning to advanced stage. China's rapid economic growth has provided an opportunity for the development of higher education. The supply side of the supply side reform existing concept of university structure imbalance of talent quality is not high efficiency low borrowing economy, higher education system supply side reform emphasizes improving supply quality, improve the supply structure, to keep pace with the development of higher education supply side reform is urgently needed. But the current education supply side products cannot meet the growing diversity of the masses, personalized needs. The reform of the supply side of the higher education came into being. The supply side reforms of higher education will play an important role in the quality of the workforces. Reform should promote the quality of education and innovation and entrepreneurship education, improve the level of scientific research, enhance social service capabilities and optimize the structure.

\section{Dilemma of demand side reform of higher education}

For a long time, the reform of higher education in our country is the demand side reform. In the investment of higher education reform, the government's investment in higher education through all kinds of human, material and financial resources, makes the rapid expansion of China's colleges and universities, there are tens of thousands of college and university. In the long run, the demand side reform has been unable to meet the needs of the development of higher education, to a large extent restricted the development of higher education in our country. Demand side reform emphasizes the greater the size of the school, the better, the more the better, but such a development path is stuck in the extension of development, does not pay attention to the connotation of the building. Especially in the current evaluation system of scientific research in our country, the school pays more attention to the positive effect of scientific research output on the promotion of university ranking and social reputation. As one of the three main functions of university teaching has been neglected, the quality of personnel training has been seriously affected. Many teachers put too much effort into research, the phenomenon of heavy research, light teaching. We should pay attention to the demand side investment reform, the main source of China's higher education funding is the government, social sharing power and coverage are small government macro-control of the colleges and universities, more control from the political system, the use of funds has not yet established a strict accountability mechanism, as to how to use the money in there is little to do the evaluation effect. The demand side reform of the concept and ideas, leading to a lot of colleges and universities do not reflect their social responsibility, especially the problem of personnel training. Although in recent years, with the university employment pressure of unprecedented increase, the University began to carry out the quality assessment, content development, etc., but mostly stay in the surface, and there is no in-depth thinking about the problem of structural adjustment. 


\section{Directions of supply side reform of higher education}

\subsection{Optimize specialty provision}

According to the regional economic and social development needs, we close docking industry and industry needs to set up the application of professional. Clear training objectives and requirements, establish an effective exit mechanism for professional excess, relax control over professional, compress and eliminate the low employment rate, personnel training and social demand of the backwardprofessional coursesandset up new professional needs of the new era, so that the elements and resources of colleges and universities to re flow, re configuration. Educating people is a long-term project. In doing the discipline layout, we must have a vision. Basic disciplines and application of different disciplines, basic science research achievements and talents must have a longterm arrangement, which is the foundation of national long-term competitiveness; but training applied disciplines and applied talents should be more practical. University education can not only be employed as the goal, but the university students must be able to obtain employment, to have a better career development potential. We must take into account the employment and future career development of college students in the society. With professional construction as the core, optimize the allocation of educational resources. On the macro level, the government should continue to increase the investment in education of higher education related to what kind of labor and technology application of future economic and social institutions, and determines the system innovation and capital efficiency in a certain extent. With professional construction as the core, optimize the allocation of educational resources. Universities should increase education funding ratio, and focus on strengthening the construction of education information infrastructure, hardware and software environment to optimize the training of applied talents.

\subsection{Reform backward courses}

Perfect course evaluation mechanism and course assessment methods, and establish the dynamic updating mechanism of curriculum application content. Design, optimize and reconstruct the curriculum structure, and gradually carry out the integration of the curriculum to form a curriculum system which is used to develop the students' practical ability and innovation ability. Make full use of modern information technology to promote the reform of curriculum content and teaching methods, the establishment of the depth of cooperation between colleges and industries, enterprises, collaborative construction curriculum resource mechanism, cooperative development courses. Because higher education has long been common in higher education teaching mode, curriculum content to highlight a subject or a class of knowledge as the foundation, emphasize systematic and complete disciplines, teachers are accustomed to impart longitudinal professional knowledge, lack of horizontal teaching group related professional knowledge, students thinking is restricted to a narrow the range of learning initiative and 
creativity is limited. At present, our country is entering the era of knowledge economy, the development of knowledge economy on the quality of talents, specifications of the multiple requirements, only to master a single knowledge skills cannot better survival and development. To improve the comprehensive quality has become an inevitable requirement of sustainable development. Therefore, curriculum design must be integrated and open.

\subsection{Cultivate new teachers}

We should improve the incentive mechanism and professional development to accelerate the introduction of professional high level professional disciplines and professional group construction need to be applied leading talents and the backbone of the teaching to promote the "double teachers" development. We should support the policy that teachers participate in the practice application research and technology research and development, production and technical personnel and management personnel hired and take the front management teaching. Reform of teacher employment and evaluation mechanism, and promote the construction of the "Double Teachers" teaching staff. The ability and level of the teachers, whether it can meet the demand of the reform of the supply side of education, can support the speed and strength of the development of education. The lack of effective supply of education demand contradiction, making the deepening of education supply side structural reform is quite urgent. Education itself is the supply side, education is the supply of talent, the allocation of educational resources, education environment to build, and can provide what kind of education, but also the supply side of the problem. To solve the problem of students, we must first solve the problem of teachers. It is not only the change of thinking and ideas, but also the change of action. Teacher is the key factor that restricts the development of pre-school education, the current development of pre-school education is the focus of the increase of resources. The key is still teachers. From the perspective of supply side reform is the most effective way to solve, such as the comprehensive promotion of education professional certification, the establishment of education professionals training standards, to build a cooperative training mechanism.

\subsection{Promote vocational education}

The development of occupation education can promote the development of economy, promote employment, improve people's livelihood. Occupation education system and realize the educational human labor employment system integration and financing, build a national qualification framework; the establishment of a national occupation education management institutions, to ensure that the national top-level design layer of occupation education policies, investment, monitoring etc. the integration and coordination. Vocational education should be geared to the needs of all people, to the society, to cultivate the students' professional ethics, vocational skills and the ability to obtain employment and entrepreneurship. Developing vocational education is an effective way to alleviate the structural contradiction of employment and to 
promote urbanization in an orderly way. So, the new normal occupation education is to adhere to the service to promote the development of employment oriented development path of docking needs and distinctive features, focus on enhancing youth employment and entrepreneurship, boosting the improvement of people's livelihood, promotes social fairness. Giving full play to the role of market mechanism, guiding social forces to participate in running schools, is to accelerate the development of modern vocational education reform orientation. To further encourage social forces in education, the new normal occupation education is to further deepen the reform of system of running mechanism, mobilize and guide the particular industry enterprises to form the pattern of public colleges and private colleges.

\section{Conclusion}

This study provides a theoretical reference for the current development of China's supply side reform of higher education. It is undeniable that the real change of the current university is still facing the academic power confrontation and administrative power confrontation. The universities should carry out the supply side reform to provide people with quality higher education services.

\section{References}

[1]Cheng Shuqiang, China's Higher Education Reform:A Perspective of the Supply Side Reform, Journal of National Academy of Education Administration, 18(8), pp. 12-16+49, 2016.

[2]Jiang Zhaohui, Leading Development of Higher Education Based on Supply Side Reforms, Chongqing Higher Education Research, 4(1), pp. 123-127, 2016.

[3] Liu Wei, Problems and Difficulties in theSupply Side of Higher Education Reform in China, Heilongjiang Researches on Higher Education, 35(10), pp. 3941, 2016.

[4]GaoQuande, Li Zhen, On the Enlightenment of Supply-Side Reform on Higher Vocational Education Development, 35(10), pp. 70-73, 2016 